\title{
Pandemic Pedagogy: Assessing the Online Implementation of a Decolonial Curriculum
}

\section{Shannon Morreira}

Humanities Education Development Unit, University of Cape Town, South Africa.

\begin{abstract}
The student protests in South Africa (2015-2017) triggered shifts in pedagogical practices, such that by 2020 many South African higher education institutions had begun to make some concrete moves towards more socially just pedagogies within teaching and learning (Quinn, 2019; Jansen, 2019). In March 2020, however, South Africa went into lockdown as a result of Covid19, and all higher education teaching became remote and non-synchronous. This paper reports on the effects of the move to remote teaching on the implementation of a new decolonial 'emplaced' pedagogy at one South African university. The idea of emplacement draws on the careful incorporation of social space as a teaching tool within the social sciences, such that students can situate themselves as reflexive, embodied persons within concrete spaces and communities which carry particular social, economic and political histories. This paper draws on data from course evaluations and student assignments, as well as a description of course design, to argue that many of the benefits of careful emplacement in historical and contemporary context can happen even where students are never in the same physical spaces as one another or their lecturers. This relies, however, on students' having access to both the necessary technology and to an environment conducive to learning.
\end{abstract}

Keywords: Online pedagogy; decoloniality in higher education; emplacement; social science; emergency remote teaching. 


\section{Introduction}

\subsection{Background: the University Context}

Since a 1997 White Paper, the higher education sector across South Africa has been under pressure from the state to transform, in order to move away from the inherited inequities that resulted from apartheid policy and planning. As Lange (2017) has noted, however, postApartheid higher education policies have also largely had a neo-liberal framing, which has led to a focus on improving access and throughput. The focus on these imperatives resulted in an absence of attention to the concomitant need for change in curricula and institutional culture (Luckett et al, 2019.) This gap was highlighted during the nationwide student protests that took place across higher education institutions between 2015 and 2017 under the banner of \#RhodesMust Fall and \#FeesMustFall. These student movements called for radical challenges to institutional practice, including the call to decolonise the curriculum and pedagogy.

Recent scholarship on teaching and learning in South Africa has shown that this call to decolonise pedagogy and curricula has had an effect on educational practices in South African universities, and many South African higher education institutions have begun steps towards more socially just or decolonised pedagogies within teaching and learning (see, for example, two recent edited collections by Quinn, 2019 and Jansen, 2019, as well as South African examples within Morreira et al, 2021). Most of these initiatives are new and were still in early stages when the country went into a nationwide lockdown in March 2020, as a result of the Covid-19 pandemic. Universities were immediately closed and students sent home, and teaching was put on pause while university management debated how to reestablish teaching and learning under a lockdown.

The landscape of higher education in South Africa (like much of the national landscape more generally) is a deeply unequal one, such that some universities have much greater stability and access to resources than others. Wangenge-Ouma and Kupe (2020:1) thus note that universities were very differently able to respond to the challenges of the Covid-19 pandemic, with well-resourced universities able to quite quickly institute online remote teaching and provide training for teaching staff in new technologies and online pedagogies, and provide students with laptops and data. Less well-resourced universities were not, however, and the 2020 academic year was finished at different times and with quite uneven results across the sector. It is worth noting at the outset of this paper, then, that any attempt at instituting socially just or decolonized pedagogy within the South African context needs to be undertaken in such a way that students' have adequate access to all learning materials, and to a conducive learning environment.

The university on which this paper focuses is a well-resourced one, that was able to quite quickly take teaching work online, under what was referred to as Emergency Remote 
Teaching (ERT). Nonetheless, in addition to the challenges of re-designing curricula for online delivery, and training staff in new technologies, the university also faced an enormous challenge in supplying all students with laptops and data such that they could access the work. In some cases this was impossible, and physical materials were delivered to students via courier in a distance learning model. Furthermore, the university was of course also unable to influence students' home learning conditions, which in the context of South Africa often involved a lockdown in crowded conditions, with no room to study or think away from other family members, and often inadequate access to food and sanitation while so doing.

\subsection{Implementing decolonial principles in pedagogy}

The course discussed here had recently been re-designed in keeping with a set of principles and questions developed at the University of Cape Town in 2017, in a working group called "Decolonising Pedagogy in the Humanities" (Morreira and Luckett, 2018). In the re-design, the convener had also been cogniscent of the idea of emplacement (Morreira et al, 2020). This perspective stems from a recognition of the fact that much social science teaching in higher education is theory-heavy, abstract, and removed from concrete engagements with the material world. This results in students and knowledge being removed from place and collaborative relationality, and existing instead within a framework of deplaced, individualized competition (ibid). The complex histories of colonialism's effects on the social world as it exists in the Global South are also elided when place and the material world are left out of the classroom. One way to resist coloniality is to thus bring place and materiality more strongly into curriculum design. The idea of emplacement thus draws on the careful incorporation of social space as a teaching tool within the social sciences, such that students can situate themselves as reflexive, embodied persons, with agency, within concrete spaces and communities which carry particular social, economic and political histories. Consciously teaching in and with place also provides a push back against disciplinary boundary policing, as multiple intersecting perspectives are necessary to understand any one place because "a place has a human history and a geologic past: it is part of an ecosystem with a variety of microsystems, it is a social, economic and political order." (Orr 1992, 186). Emplacement thus also carries the potential to allow students to begin a critical, engaged re-thinking of place and socio-political history.

Concepts in Social Science was re-designed in early 2020 in line with these principles. The course is a first year offering, delivered exclusively to students on an extended degree programme, and aims to provide first year students with the tools to critically read, analyse and engage with key social science texts and concepts, including situating the students as nascent knowledge-makers/researchers in the social sciences. In what follows, I discuss the ways in which it was possible to institute decolonial principles of emplacement in the course as run online under ERT. While other decolonial elements were included in the course, such as multilingualism for example, the analysis here focuses on those parts concerned with 
emplacement. Data presented in this paper was drawn from the course outline and online course site; students' assignments and results; and responses to a course evaluation taken by 67 out of the 179 students in the class. In all cases students have been kept anonymous.

\section{Findings and Analysis}

\subsection{Course Design}

Prior to 2020's nationwide lockdown, the course was intended to be delivered face to face, and included students' engaging with the world on and beyond the university campus, through fieldtrips and assessment tasks that required engagement with place. The course was arranged around a core theme of the social geographies of Cape Town, which was defined as the study of how and why we occupy physical space and place in the way that we do, through the study of social relations, social identities and social inequalities as they play out within they city. While it was no longer possible to teach with and in Cape Town in situ, as many students were not even in Cape Town for the course but had been sent home to various parts of South Africa, the key theme of Cape Town was kept, and it was approached through online remote teaching instead. Using the university's e-learning system, the course was laid out in an easy to follow weekly system, and students asynchronously ${ }^{1}$ accessed set readings, short lecture videos, and active learning tasks each week. The course was split into two halves: in the first half, weekly modules were taught under the overarching theme of 'Social Geographies: Situating Ourselves', which included modules on 'Origins: The Many Names of Kaapstad'; 'Identity, Space and Place'; and 'Monuments and Memorials', which all set out to explore the complex social history of Cape Town - as KhoiSan territory; colonial outpost; apartheid city; and post-apartheid city - and allowed students to situate themselves within this social history. This first term also introduced the idea of social science as a means of making knowledge within a postcolonial/settler society, asking what it means to conduct research, what some of the histories of this kind of work are, and how and why we might conduct our own research in the present in such a context. In the second term, under the overarching theme of 'Concepts in Social Science: Ways of Knowing the City and Ourselves Within It' the modules used key concepts in social science - such race, gender, inequality, and xenophobia - to explore beneath Cape Town's surface. The course asked that students

\footnotetext{
${ }^{1}$ A key principle of ERT was that it needed to be as low technology as possible, to allow students with limited access to data to access materials. The university struck a deal with cell phone companies such that the university's learning system would be 'zero-rated', ie would carry no monetary costs to students to access, but even so many students lived in areas with inadequate cell phone reception coverage where the possibilities for internet/data connections were poor. As such, all teaching was asynchronous; students were offered different sizes of video for download, or could access just a transcript and set of slides; or they had the option to have hard copies of materials and flash drives with electronic materials delivered to their homes.
} 
and lecturers work together towards imagining a city that sustains all its' peoples, thinking through what social science can teach us about how the city currently is, and what we can imagine differently. Modules in this term thus covered themes such as Race and Racialisation: What Understanding Structure Can Tell us about Agency; Land and Legacy: Inequality in the City; and Nationality and Xenophobia, for example.

While students were not physically present within a classroom space in Cape Town, then, the course was designed in such a way that the principles of emplacement, through which students can begin a critical, engaged re-thinking of place and socio-political history, still underpinned design. Whilst no fieldtrips were possible, the students were still able to remotely explore the campus and city within which their University is located. Grading was done on the basis of continual assessment, with marks split between smaller, low-stakes weekly active learning tasks (eg. 'What elements of your culture really matter to you? Where do you think you learned them?') and higher weighted submissions, including a multilingual glossary of terms, and a research project. This final assessment of the course required that students conduct a small piece of research, in which they either interviewed someone who they were in lockdown with, or did an auto-ethnographic reflection on their own lives, using core concepts the course had explored for their analysis. ${ }^{2}$ Given that many students were at home in lockdown under less than ideal learning conditions, this allowed students to link concepts such as structure, race, governmentality and inequality to the materiality of their own lives under lockdown, as well as enabling students to harness the idea of agency to think through those parts of their daily lives over which they could exert control. Students were thus able to take the concepts from the course into their own daily lives, and into the real world, such that the materiality of space and place could still be present in their learning. The following excerpt from a final student assignment in which they reflected on the course in general give a sense of the ways in which this enabled students to reflexively engage with the concepts in ways that situated them within post-apartheid Cape Town:

"Throughout the duration of the course I was reintroduced to many concepts that I used on a daily basis. This reintroduction allowed me to think about concepts and their ideas differently and to see them through new, socially constructed eyes. Through this I have

\footnotetext{
${ }^{2}$ This task required that students 'conduct either an oral history with a household member, or an auto-ethnographic reflection on your own life, around the theme of 'social geographies' (defined as 'reflecting on people and their environment, with a particular emphasis on social factors.')' Auto-ethnography is an anthropological method; students using this method were tasked with 'thinking carefully and critically about your own life experiences, so as to use them as data that can be analysed and presented to us in narrative form.' The project was broken down into three smaller tasks: students first wrote a concept note, outlining their idea for research and their preferred methodology; after they had been given feedback on this they then submitted a transcript or recording of the interview they had conducted, or auto-ethnographic fieldnotes; followed by a final research report, which followed a set structure they were guided through in class.
} 
realized that safe, welcoming and open green spaces tend to nurture me, spaces like environmentally friendly parks, perhaps even public waterfalls. These type of spaces not only sustain me, but they aim too at ensuring that people of different backgrounds can come together in the city of Cape Town and grow together towards a more liberal and equal city. I envision Cape Town to become a city that through equality disregards the separation enforced on generations of people. I would like to see the country too move in ways that will shape individuals into becoming free and socially educated in terms of the possibilities we as society can reach."

\subsection{Results from the Course Evaluation}

The course evaluation was completed by 67 of 171 students (39\%), and showed students to have responded well to the theme of social geographies of Cape Town. $73 \%$ of respondents agreed with the statement 'I enjoyed using Cape Town as a focal point for exploring concepts in the social sciences.' Qualitative statements from students in keeping with this theme included, "I loved it, it's so much easier to study complicated concepts through every day things,"; "I valued when we learnt about identity and space and how it affects who we are", and "The course inspired critical thinking about who and where we are." Students also valued that the research project situated them as knowledge-makers within the academy, even as first year students, and allowed them to draw on their everyday lives in working with complex concepts. $79 \%$ of students thus agreed with the statement, "I found the research project useful for putting concepts into practice and developing my skills as a social scientist in the Global South." Qualitative statements in keeping with this theme included "I value the skills and the effort that is taken into conducting research. I learned that it was not only about asking questions but also linking up certain parts of our history together to form one, coherent storyline"; and, "I really valued being able to interview my own grandfather about his life experiences, and recognise how that fits into the history of our country, and can be analysed using the concepts we have been working with this semester."

\subsection{Students' Course Results}

The table below compares student result in 2019 (face to face implementation) with student results in 2020 (remote implementation). Note that the content, assessment methods and mode of delivery were all changed considerably in 2020: but the National Qualification Framework (NQF) level, which measures applied competence, remained the same. 
Table 1. Comparison of Student Results 2019 and 2020, as a percentage of the class as a whole.

\begin{tabular}{lll}
\hline & $\mathbf{2 0 1 9}$ & $\mathbf{2 0 2 0}$ \\
\hline Passes & 90,9 & 88,3 \\
First Class Pass & 13,8 & 22,5 \\
Fails & 2,1 & 1 \\
Incompletes & 6 & 10,7 \\
\hline
\end{tabular}

The category 'Pass' shows cases where students received over $50 \%$ for the course. The category 'First Class Pass' shows a pass grade of over 75\%. The category 'Fail' shows cases where students submitted all tasks but received a final coursework mark of less than $50 \%$. The category 'Incomplete' shows cases where students did not pass the course because they did not submit enough work to reach the $50 \%$ grade requirement.

The table thus shows that there was a small drop in student passes in 2020; but that the percentage of passes in the First Class category (a grade of $75 \%$ and above) was higher in 2020 than in 2019. It also shows a drop in the percentage of those who failed even after submitting all tasks. The data sets and changes year on year are of course small: nonetheless, they indicate that where students were able to access content and focus on learning, the course was able to fulfil its aims, despite ERT. However, the table also shows an increase in the percentage of students who did not submit enough work to pass the course. This increase in Incompletes likely indicates that the effects of social conditions of lockdown in South Africa (such as crowded learning conditions, increased mental health strain) impacted on some students' ability to complete work, despite work being delivered to students in hard copy and on flash drives where internet capacities were insufficient. The rise in Incompletes highlights the difficulty of implementing a decolonial, socially just curriculum where the conditions under which students are able to learn are unequal, even where they have equal access to teaching materials.

\section{Conclusion}

This paper has considered the effectiveness of implementing a curriculum of emplacement under Emergency Remote Teaching during the South African lockdown. It has thus focused on those parts of the course that could be said to be employing a pedagogy of emplacement. The paper shows that it is possible to enact a pedagogy of emplacement even from a distance, through content and assessment methods that enable students to position themselves as reflective, agentic persons situated in places with complex histories. However, it also argues that there are broader difficulties in implementing a decolonial or socially just curriculum where students' social conditions are not all equally conducive to learning. It is likely that 
the pandemic will result in continued remote teaching in South African higher education for all of 2021, and possibly even some of 2022, depending on the availability of vaccines. The paper thus recommends that university-run student residences be re-opened (under appropriate social distancing measures), and that students who are vulnerable to poor home conditions for learning be prioritized for placement in those residences.

\section{References}

Lange, L. (2017). Twenty Years of Higher Education Curriculum Policy in South Africa. Journal of Education, 67, 28 - 45. Doi: 10.17159/2520-9868/i68a01

Morreira, S and Luckett, K. (2018). 'Questions Academics Can Ask to Decolonise their Classrooms.' Retrieved from https://theconversation.com/questions-academics-can-askto-decolonise-their-classrooms-103251

Luckett, K; Morreira, S. and Baijnath, M. (2019). 'Decolonizing the Curriculum: Recontextualization, Identity and Self-critique in a Post-apartheid University' in Quinn, L. (2019). Reimagining curriculum: spaces for disruption. Stellenbosch: SUN Media.

Jansen, J. (2019) (ed) Decolonisation in Universities. Johannesburg: Wits University Press.

Morreira, S., Taru, J. and Truyts, C. (2020). Place and Pedagogy: Using Space and Materiality in Teaching Social Science in Southern Africa, Third World Thematics: $A$ TWQ Journal 5(1-2), 137-153. Doi: 10.1080/23802014.2020.1747944

Morreira, S., Luckett, K., Kumalo, S and Ramgotra, M. (eds), (2021). Decolonising Curricula and Pedagogy in Higher Education: Bringing Decolonial Theory into Contact with Teaching Practice. London: Routledge.

Orr, D. (1992). Place and Pedagogy. The NAMTA Journal, 38(1), 183 -186

Quinn, L. (2019). Re-imagining Curriculum: Spaces for Disruption. Stellenbosch: SUN Media.

Wangenge-Ouma, G. and Kupe, T. (2020). Uncertain Times: Re-imagining Universities for New, Sustainable Futures. Universities South Africa (USAF) Discussion Document. Retrieved from https://www.usaf.ac.za/covid-19-fosters-a-need-to-re-imagine-theuniversity-as-a-social-institution/ 